\title{
PENGARUH TEMPERATUR TERHADAP SIFAT MEKANIK PADA PEMBUATAN PAPAN KOMPOSIT BERBASIS SEKAM PADI DAN MATRIKS HDPE
}

\author{
Kardiman $^{1}$, Fauzan D.S Fuadi ${ }^{2}$, Faradina C.S ${ }^{3}$, Eri Widianto ${ }^{4}$ \\ ${ }^{(1,2,3,4)}$ Teknik Mesin, Fakultas Teknik, Universitas Singaperbangsa Karawang \\ JL. H. S. Ronggowaluyo TelukjambeTimurTelp. (0267) 641177 Ext. 305-Karawang 41361 \\ kardiman@ft.unsika.ac.id
}

\begin{abstract}
ABSTRAK
Ketergantungan pada bahan buatan komposit yang semakin tinggi menuntut terciptanya inovasi untuk mengembangkan material yang lebih ramah lingkungan tanpa meninggalkan pengembangan teknologi hijau atau teknologi ramah lingkungan semakin serius dikembangkan. Penelitian ini bertujuan untuk menganalisa pengaruh temperatur pencetakan papan komposit $160^{\circ}, 180^{\circ} \mathrm{C}, 200^{\circ} \mathrm{C}$, dan $220^{\circ} \mathrm{C}$ menggunakan metode penempaan (Hot Press) berbahan dasar limbah sekam padi sebagai penguat dan HDPE Recycle. Sebelumnya sekam padi dilakukan proses alkalisasi terlebih dahulu untuk menghilangkan lapisan lignin (lilin) yang terkandung pada serat alam, dimana sekam direndam dalam larutan $\mathrm{NaOH}$ sebanyak 5\% selama 2 jam. Spesimen yang di uji pada penelitian ini adalah uji makro dan uji tarik uji, pengujian tarik dibuat mengacu pada standar ASTM D 638-02, pengujian tarik yang dimaksud yaitu untuk menggetahui sifat mekanik dan pengujian foto makro yakni untuk mengetahui sifat fisik papan komposi. Dari hasil Pencetakan Papapan Komposit setiap variasi suhu berdimensi $398 \mathrm{~mm}$ x $178 \mathrm{~mm}$ dengan ketebalan $\pm 10 \mathrm{~mm}$. Suhu $160^{\circ} \mathrm{C}$ dan suhu $180^{\circ} \mathrm{C}$ terlihat jelas HDPE tidak melapisi secara menyeluruh terutama pada bagian pinggir cetakan namun pada penyatuan sekam padi HDPE bagian tengahnya terlihat lebih menyatu dengan optimal. Sedangkan pada suhu $200^{\circ} \mathrm{C}$ dan $220^{\circ} \mathrm{C}$ terlihat sangat jelas bahwa HDPE sangat mendominasi cetakan dibandingkan sekam padi, sehingga HDPE melapisi sekam padi dengan optimal untuk ketebalan dari papan komposit menjadi lebih pipih dibandingkan dengan suhu $160^{\circ} \mathrm{C}$ dan suhu $180^{\circ} \mathrm{C}$. Hasil Foto makro menjelaskan pada suhu $160^{\circ} \mathrm{C}$ dan suhu $180^{\circ} \mathrm{C}$ sekam padi terlihat jelas mengisi di bagian tengah spesimen, sedangkan pada suhu $200^{\circ} \mathrm{C}$ dan suhu $220^{\circ} \mathrm{C}$ sekam terlihat sekam sudah mengalami penyusutan dan tampak hangus sehingga HDPE lebih mendominasi papan komposit. Hasil uji Tarik memiliki beban maksimal dan kekuatan tarik pada pembuatan papan komposit pada suhu $160^{\circ} \mathrm{C}$ yaitu $678,02 \mathrm{~N}$ dan 9,1406 Mpa serta memiliki perpanjangan akhir dan regangan akhir yaitu $0,515 \mathrm{~mm}$ dan $1,03 \%$.
\end{abstract}

Kata kunci: Sekam padi, Plastik HDPE, Hot press, Sifat fisik, Sifat Mekanik

\section{ABSTRACT}

Effect of Temperatures on Mechanical Properties in Making Composite Boards of Rice Husk and HDPE as Matrix. The increasing dependence on composite artificial materials requires innovation to develop materials that are more environmentally friendly without leaving. The development of green technology or environmentally friendly technology is increasingly being seriously developed. This study aims to analyze the effect of printing temperature of composite boards of $160^{\circ} \mathrm{C}, 18{ }^{\circ} \mathrm{C}, 200^{\circ} \mathrm{C}$, and $220^{\circ} \mathrm{C}$ using forging method (Hot Press) based on rice husk waste as reinforcement and HDPE Recycle. Composite board manufacturing is done by varying the mold temperature of $160^{\circ} \mathrm{C}, 18^{\circ} \mathrm{C}, 200^{\circ} \mathrm{C}$, and $220^{\circ} \mathrm{C}$ in the volume ratio between rice husk and HDPE Recycle by $20 \%$ and $80 \%$. Previously, rice husk was alkalized before removing the layer of lignin (wax) contained in natural fibers, where the husk was immersed in a 5\% NaOH solution for 2 hours. The specimens tested in this study were macro test and tensile test, tensile testing was made according to ASTM D 638-02 standard, tensile testing meant to know the mechanical properties and macro photo testing namely to find out the physical properties of the composition board. From the results of Printing Composite Staple each temperature variations dimension $398 \mathrm{~mm} \times 178 \mathrm{~mm}$ with a thickness of $\pm 10 \mathrm{~mm}$. The temperature is $160{ }^{\circ}$ Cand the temperature of $180^{\circ} \mathrm{Cis}$ clear that HDPE does not coat the whole, especially on the edges of the mold, but the integration of HDPE-rice husk in the middle looks more integrated with the optimal. While at $200^{\circ} \mathrm{Cand} 220^{\circ} \mathrm{Cit}$ is very clear that HDPE dominates the mold compared to rice husk, so that HDPE coated the rice husk optimally for the thickness of the composite board to be flatter than $160^{\circ} \mathrm{Cand} 180^{\circ} \mathrm{C}$. Macro photo results explain that at $160{ }^{\circ} \mathrm{Cand} 180^{\circ} \mathrm{Cthe}$ rice husk clearly fills in the middle of the specimen, while at $200{ }^{\circ} \mathrm{Cand} 220$ ${ }^{\circ} \mathrm{Cthe}$ husk has shrunk and appears scorched so HDPE dominates the composite board. Tensile test results have a maximum load and tensile strength in the manufacture of composite boards at temperatures of 160 namely $678.02 \mathrm{~N}$ and $9.1406 \mathrm{MPa}$ and have a final extension and final strain of $0.515 \mathrm{~mm}$ and $1.03 \%$.

Keywords: Rice husk, HDPE Plastic, Hot press, Physical properties, Mechanical properties

\section{PENDAHULUAN}

Ketergantungan pada bahan buatan komposit yang semakin tinggi menuntut terciptanya inovasi untuk mengembangkan material yang lebih ramah lingkungan tanpa meninggalkan aspek-aspek keselamatan dan kesehatan untuk terciptanya mutu kehidupan yang lebih baik. Pengembangan teknologi hijau atau teknologi ramah lingkungan semakin serius dikembangkan. Salah satunya adalah 
teknologi komposit dengan material serat alam (Natural Fiber). Tuntutan teknologi ini disesuaikan juga dengan keadaan alam yang mendukung untuk pemanfaatannya secara langsung [1].

Padi merupakan salah satu produk utama pertanian yang ada di negara agraris seperti Indonesia, diketahui bahwa pada proses penggilingan padi sendiri menghasilkan $72 \%$ beras, $5 \%$ dedak, dan 20-22 \% adalah sekam [2]. Hasil limbah dari sekam padi sendiri sebagian besar baru dimanfaatkan sebagai bahan bakar konvensional sehingga pemanfaatannya belum secara optimal. Pada sekam padi banyak memiliki kandungan ligninselulosa yang menimbulkan sifat kuat dan kaku. Melihat dari sifat kuat dan kaku dari sekam padi sangat optimal untuk dilakukan pengolahan lanjut menjadi bahan material komposit dan sebagai isolator panas $[2,3]$.

Salah satu cara untuk mengatasi sekam padi yang begitu besar jumlahnya menjadi komposit adalah dengan menggunakan mesin Hot Press untuk membuat atau memproduksi papan komposit. Dengan adanya teknologi mesin Hot Press dan bahan campuran cacahan plastik, sekam padi bisa dijadikan produk yang bernilai. Plastik yang digunakan yaitu plastik jenis HDPE (High Density Polyethylene) plastik jenis ini banayak ditemukan dalam bentuk kantung plastik yang dipakai oleh masyarakat pada kehidupan sehari-hari, plastik HDPE berfungsi sebagai matriks pengikat komposit yang dipanaskan dengan memvariasikan suhu dari $160^{\circ} \mathrm{C}, 180^{\circ} \mathrm{C}, 200^{\circ} \mathrm{C}, 220^{\circ} \mathrm{Cdan}$ kemudian di press. Beberapa peneltian tentang pembutan papan komposit dengan memanfaatkan serat alam sebagai penganti fiberglas.

Penelitian yang dilakukan oleh Fauziah, dkk. (2014) yaitu dengan perbandingan praksi volume partikel sekam 60\% dan sekam halus $40 \%$ ditambah perekat jenis Urea Formaldehyda (UF) sebesar 18\%, 20\%, dan $22 \%$ mendapatkan hasil sifat fisis papan partikel sekam padi pada sifat kerapatan $0,703 \mathrm{gr} / \mathrm{cm}^{3}$ sampai $0,709 \mathrm{gr} / \mathrm{cm}^{3}$ dan kadar air sebesar $8,75 \%$ sampai 9,92\% memenuhi standar JIS A 5908-2003. Sedangkan sifat mekanik papan partikel sekam padi tidak memenuhi standar JIS A 5908-2003 [4].

Witono dkk (2014), meneliti pengaruh alkalisasi dengan $\mathrm{NaOH}$ melalui perendaman selama 2 jam pada struktur komposit berpenguat serat alam (serat kelapa, serat pisang dan serat padi) berpenguat matriks empoxy resin. Kekuatan tarik tertinggi diperoleh adalah pada papann komposit menggunakan serat kelapa sebesar $60,18 \mathrm{~kg} / \mathrm{cm}^{2}$, sedangkan untuk serat padi sebesar $34,91 \mathrm{~kg} / \mathrm{cm}^{2}$ dan serat pelepah pisang sebesar $50,07 \mathrm{~kg} / \mathrm{cm}^{2}$ [5]

Sulaiman dan Ahmad Fauzan (2018), meneliti tentang perbedaan temperatur cetakan $150{ }^{\circ} \mathrm{C}, 160$ ${ }^{\circ} \mathrm{C}, 170{ }^{\circ} \mathrm{C}, 180{ }^{\circ} \mathrm{C}$, dan $190{ }^{\circ} \mathrm{Cdengan}$ selama 15 menit, hasil penelitian menunjukkan nilai rata-rata keteguhan lentur yang paling tinggi adalah 4443,441 $\mathrm{kgf} / \mathrm{cm}^{2}$ yaitu pada temperatur $190^{\circ} \mathrm{Csedangkan}$ nilai rata-rata keteguhan lentur yang paling rendah adalah $1135,205 \mathrm{kgf} / \mathrm{cm}^{2}$ yaitu pada temperatur $160^{\circ} \mathrm{C}$. Hal ini membuktikan bahwa temperatur dies sangat berpengaruh terhadap kekuatan mekanik papan komposit yang dihasilkan [6]. Penelitian ini untuk menganalisa pengarujh temperatur pada pembuatan papan komposit berbahan dasar limpah sekem padi dan matrik HDPE sebagai penguat menggunakan metode penempaan (hotpress) pengujian tarik mengacu pada standar ASTM D638 dan pengujian sifat fisik menggunakan foto makro.

\section{METODE}

Papan komposit dicetak mengguanakan mesin Hotpress di Laboratorium Produksi Fakultas Teknik Universitas Singaperbangsa Karawang, Proses foto makro dan Pengujian sifat mekanik komposit berupa uji tarik dilakukan di Balai Besar Bahan dan Barang Teknik (B4T) Bandung.

\subsection{Alat dan Bahan}

Alat Hot Press yang digunakan pada proses pencetakan papan komposit merupakan alat yang dirancang sebelumnya, yang berfungsi untuk memadatkan matriks dan serat menjadi papan komposit menggunakan sistem hidrolik penekanan panas, seperti ditunjukan pada Gambar 1. Mesin hotpress hidrolik [7]. 


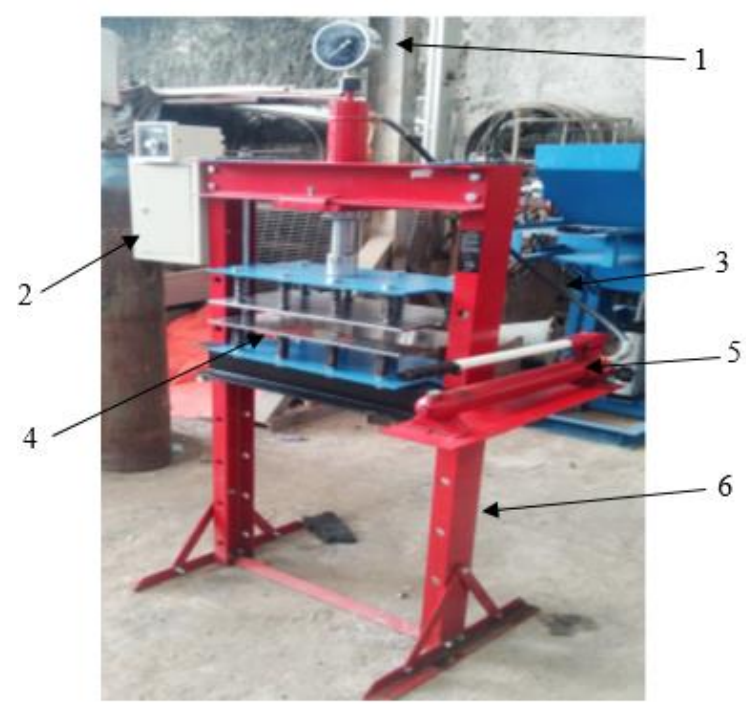

Gambar 1. Mesin hotpress hidrolik.

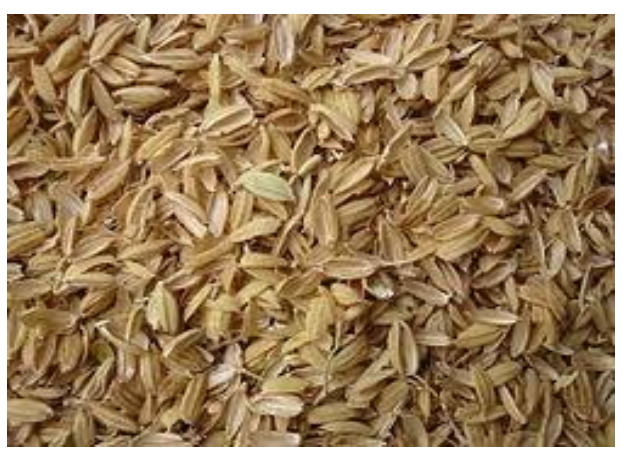

Gambar 2. Sekam Padi

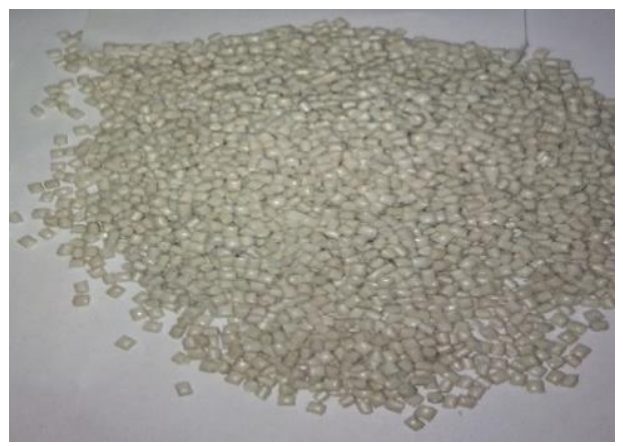

Gambar 3. Biji plastik HDPE recycle

Alat Hot press yang ditunjukan pada Gambar 1 terdiri dari beberapa komponen (1) Pressure gauge, (2) Panel listrik, (3) Selang, (4) Cetakan, (5) Hidrolik, (6) Rangka. Bahan baku yang digunakan pada proses pembuatan papan komposit sekam padi ditunjukan pada Gambar 2 Sekam padi dan biji plastik HDPE Recycle ditunjukan pada Gambar 3 sedangakan bahan yang lain adalah Alumunium Foil, Wax Mold Release larutan ( $\mathrm{NaOH}$, Aquades).

\subsection{Pembuatan Papan Komposit}

Limbah sekam padi yang digunakan sebelumnya di alkalisai terlebih dahulu dengan tujuan untuk menghilangkan lapisan lilin dan lender pada sekam padi. Proses perlakuaan alkalisasi menggunakan larutan $\mathrm{NaOH} 5 \%$ dan pelarut Aquades selama 2 jam dan dikeringkan di bawah sinar matahari dengan asumsi bahwa sekam padi sudah benar-benar kering. Pencetakan papan komposit dimulai dengan mencampurkan sekam padi dan biji plastik HDPE samapai merata atau homogen seperti di tunjukan pada Gambar 4 dan mengvariasikan matriks dan serat antara lain:

1. $20 \%$ serat $+80 \%$ matrisk suhu $160{ }^{\circ} \mathrm{C}$

2. $20 \%$ serat $+80 \%$ matriks suhu $180^{\circ} \mathrm{C}$

3. $20 \%$ serat $+80 \%$ matriks suhu $200{ }^{\circ} \mathrm{C}$

4. $20 \%$ serat $+80 \%$ matriks suhu $220^{\circ} \mathrm{C}$

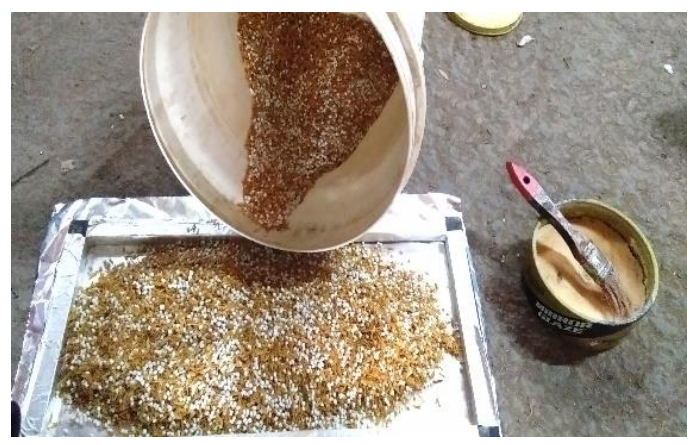

Gambar 4. Proses pencampuran sekam padi dan biji plastik HDPE

Pembuatan papan komposit menggunakan dies dengan ukuran $398 \mathrm{~mm}$ x $178 \mathrm{~mm}$ x $10 \mathrm{~mm}$ sedangan tekanan pengepresan pengepresan papan komposit \pm 1 ton. Suhu yang di variasikan pada pembuatan papan komposit yakni $160{ }^{\circ} \mathrm{C}, 180{ }^{\circ} \mathrm{C}$, $200{ }^{\circ} \mathrm{C}$, dan $220{ }^{\circ} \mathrm{Cdengan}$ konsentrasi $20 \%$ serat $80 \%$ matris sehingga papan yang dihasilkan berjumlah 4 papan dengan variasi suhu yang berbeda.

\subsection{Pengujian Papan Komposit}

Pengujian Foto Makro dilakukan untuk melihat hasil pencetakan papan persetiap suhu sedangakan pengujian Tarik Papan di bentuk sesuai dengan 
standar ASTM D638 ditunjukan pada Gambar 5 Spesimen Tarik $20 \%$ sekam: $80 \%$ HDPE.
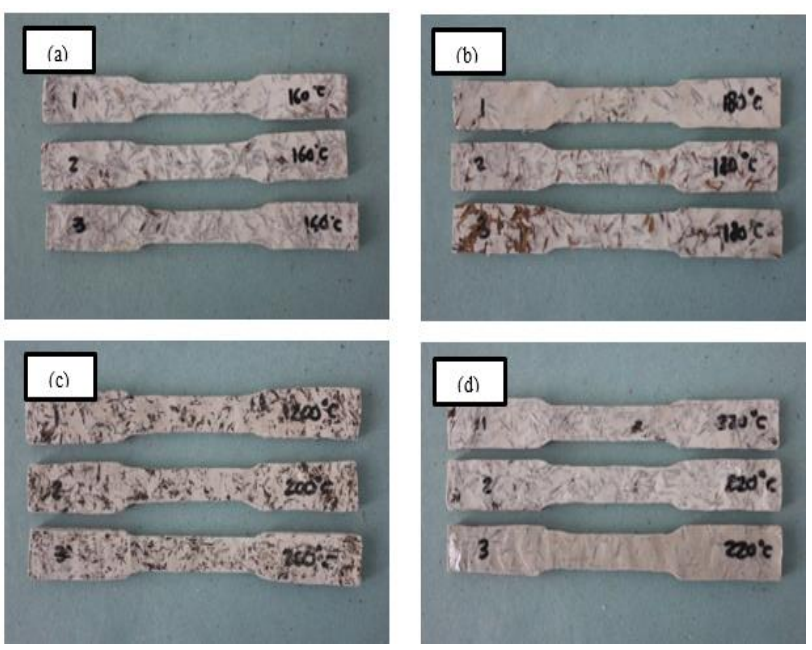

Gambar 5. Spesimen tarik $20 \%$ serat: $80 \%$ proses pembuatan hot press suhu (a) $160{ }^{\circ} \mathrm{C}$, (b) $180{ }^{\circ} \mathrm{C}$, (c) $200{ }^{\circ} \mathrm{C}$, dan (d) $220^{\circ} \mathrm{C}$

Hasil uji tarik tersebut nanti akan tervisualisasi dalam bentuk grafik pada komputer yang terhubung ke mesin uji. Data uji tarik terekam di komputer lalu selanjutnya diolah untuk mengetahui hasilnya seperti kekuatan beban maksimal (Maximum Point Load), kekuatan tarik maksimal (Maximum Point Stress), kekuatan perpanjangan akhir (Break Point Elongation), kekuatan regangan akhir (Break Point Strain). Hasil data pengujian komposit selanjutnya akan dibuat grafik yang diambil dari nilai rata-rata keseluruhan.

\section{HASIL DAN PEMBAHASAN}

Hasil dan pembahasan pada penelitian ini menyangkut tentang hasil pencetakan papan komposit sekam padi matriks HDPE kemudian dilakukan pengujian fisis komposit sifak mekanik.

\subsection{Pencetakan Papan Komposit}

Pengaruh temperatur memepengaruhi hasil pencetakan papan komposit disetiap variasi, Gambar 6 (a) menunjukkan hasil pencetakan papan komposit suhu $160{ }^{\circ} \mathrm{C}$, Gambar 6 (b) menunjukkan hasil pencetakan papan komposit suhu $180{ }^{\circ} \mathrm{C}$, Gambar 6 (c) menunjukkan hasil pencetakan papan komposit suhu $200{ }^{\circ} \mathrm{Cdan}$ Gambar 6 (d) menunjukkan hasil pencetakan papan komposit suhu $220{ }^{\circ} \mathrm{C}$. Terlihat pada Gambar 6 (a) dan gambar 6 (b) terlihat jelas HDPE tidak melapisi secara menyeluruh terutama pada bagian pinggir cetakan namun pada penyatuan sekam padi-HDPE bagian tengah terlihat lebih menyatu dengan optimal. Sedangkan gambar 6 (c) dan gambar 6 (d) terlihat sangat jelas bahwa HDPE sangat mendominasi cetakan dibandingkan sekam padi, sehingga HDPE melapisi sekam padi dengan optimal untuk ketebalan dari papan komposit menjadi lebih pipih dibandingkan penjelasan papan komposit pada gambar 6 (a) dan gambar 6 (b), hal ini didasari pada karakteristik dari HDPE yang mana titik lelehnya berkisar antara $120^{\circ} \mathrm{C}-135^{\circ} \mathrm{C}[8]$.

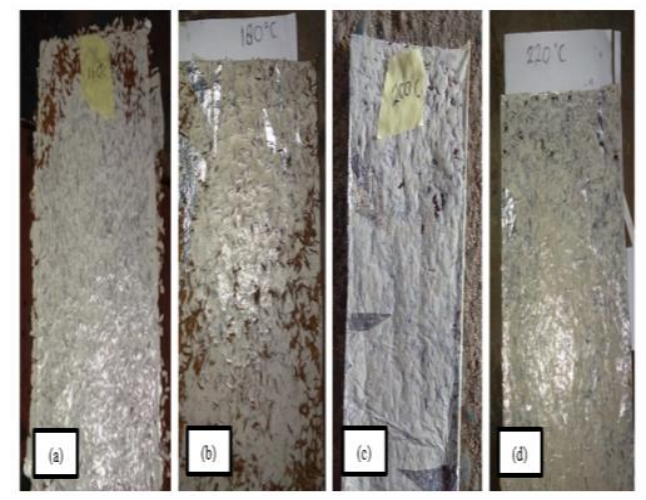

Gambar 6. (1) Hasil perlakuan sekan, (2) Hasil pencetakan papan komposit

Seperti penelitian Nurhidayat (2014) yang menyatakan partikel matriks yang dominan akan mampu mengikat komposit secara optimal, lalu jumlah serat yang semakin sedikit menimbulkan potensi menurunnya kekuatan komposit, fenomena tersebut disebabkan semakin sedikit fraksi volume serat akan meningkatkan rongga atau pori-pori pada komposit, semakin meningkat jumlah rongga yang dihasilkan maka kekuatan komposit akan semakin menurun [9].

\subsection{Pengujian Foto Makro}

Hasil pengujian foto makro papan komposit fraksi $20 \%$ sekam: $80 \%$ HDPE terdapat adanya perbedaan susunan struktur komposit serat, nilai dari pengujian sifat fisis dan mekanik yang terdapat di setiap masing-masing variasi suhu antara $160{ }^{\circ} \mathrm{C}$, $180{ }^{\circ} \mathrm{C}, 200^{\circ} \mathrm{C}$ dan $220^{\circ} \mathrm{C}$. Factor-faktor lain yang dapat mempengaruhi disetiap pengujian specimen yaitu lamanya pemanasan mesin hot press yang kurang maksimal dalam mencapai suhu yang diinginkan Pengamatan makro susunan struktur dari 
sekam dengan HDPE, pengamatan dilihat dari bagian papan komposit yang telah di potong dengan gergaji besi. Perbesaran foto makro seperti yang di tunjukan pada gambar 8 - gambar 11. Bagian yang dilihat dari foto makro merupakan bagian sisi hasil potongan atau ketebalan specimen, maka papan komposit di potong berbentuk segi empat $(5 \mathrm{~cm} \times 5$ $\mathrm{cm}$ ) dengan ketebalan $1 \mathrm{~cm}$.

Gambar 8 menunjukan hasil foto makro dengan suhu $160{ }^{\circ} \mathrm{Cselama} 3$ jam pengepresan. Pada pembesaran foto makro terlihat bentuk dan warna dari sekamHDPE tidak mengalami perubahan. Penyatuan HDPEnya kurang menutupi bentuk dari sekam, dan terdapat banyak rongga yang cukup besar. Hal ini disebabkan dari fraksinya, kemudian dari sifat bentuk sekam yang tidak berubah dikarenakan sekam yang tahan terhadap suhu dibawah $200{ }^{\circ} \mathrm{C}$, untuk sifat dari HDPE dikarenakan titik lelehnya berkisar $120^{\circ} \mathrm{C}-135^{\circ} \mathrm{C}[9,10]$ maka tidak terlalu jauh dengan penyetelan mesin hot press di suhu 160 ${ }^{\circ}$ Csehingga warna dari HDPE juga tidak berubah.

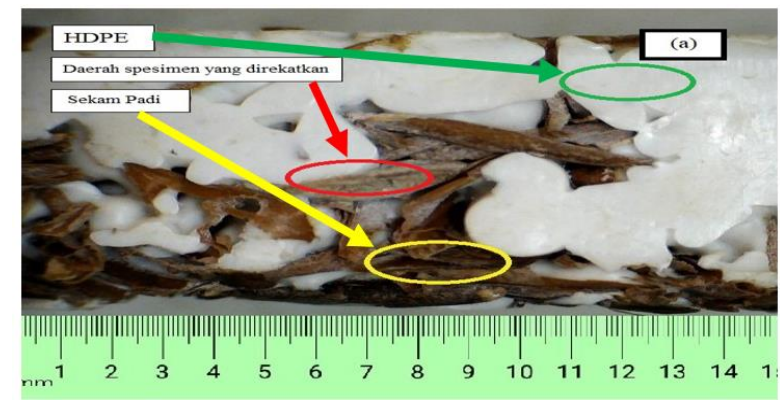

Gambar 7. Foto makro papan komposit proses hotpress suhu $160^{\circ} \mathrm{C}$.

Gambar 9 menunjukan hasil foto makro dengan suhu $180^{\circ} \mathrm{Cselama} 3$ jam pengepresan. Pada pembesaran foto makro terlihat serupa seperti papan komposit dengan pembuatan suhu $160{ }^{\circ}$ Cdari bentuk dan warna dari sekam-HDPEnya, hanya saja sekam padi sudah mulai mengalami penyusutan dari bentuk aslinya. Secara keseluruhan penyatuan antara sekam-HDPE menutupi dengan baik, namun masih terdapat banyak rongga yang terlihat dikarenakan penyatuan sekam-HDPE kurang menyeluruh. Hal ini juga disebabkan fraksinya, kemudian sifat dari bentuk sekam yang masih tahan terhadap suhu dibawah $200{ }^{\circ} \mathrm{C}$, untuk sifat dari HDPE karena titik lelehnya berkisar $120{ }^{\circ} \mathrm{C}-135{ }^{\circ} \mathrm{C}[12]$ maka masih tidak terlalu jauh dengan penyetelan mesin hot press di suhu $180^{\circ}$ Csehingga warna dari HDPE juga tidak berubah.

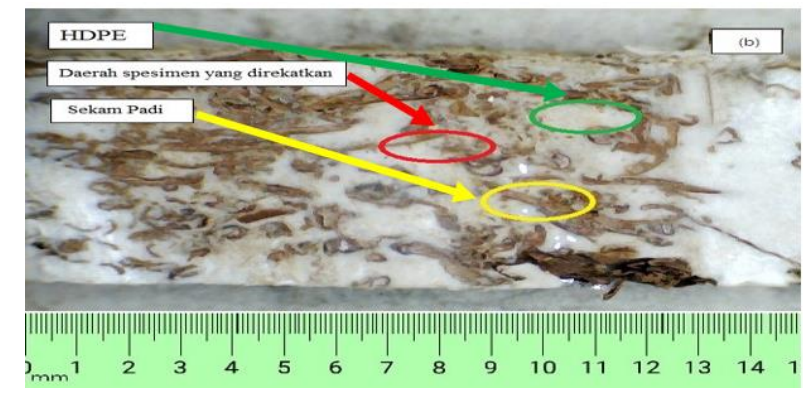

Gambar 8. Foto makro papan komposit proses hotpress suhu $180^{\circ} \mathrm{C}$

Gambar 10 menunjukan hasil foto makro dengan suhu $200{ }^{\circ}$ Cselama \pm 5 jam pengepresan. Pada pembesaran foto makro terlihat sudah mulai adanya perubahan bentuk dari papan komposit dengan pembuatan suhu $200{ }^{\circ} \mathrm{Cdari}$ bentuk dan warna dari sekam-HDPEnya, seperti sekam padi sudah mulai mengalami penyusutan dari bentuk aslinya dan juga terlihat hangus atau gosong. Secara keseluruhan penyatuan antara sekam-HDPE menutupi dengan baik, namun masih terdapat banyak rongga yang terlihat dikarenakan penyatuan sekam-HDPE kurang menyeluruh. Hal ini juga disebabkan fraksi dari sekam-HDPE, kemudian sifat dari warna dan bentuk sekam yang dipanaskan sudah mencapai suhu 200 ${ }^{\circ} \mathrm{C}$, untuk sifat dari HDPE juga sudah mengalami perubahan dikarenakan sudah menajauhi titik lelehnya berkisar $120{ }^{\circ} \mathrm{C}-130{ }^{\circ} \mathrm{C}[13]$ maka jarak suhu sudah jauh pada pembuatan dengan penyetelan mesin hot press di suhu $200{ }^{\circ}$ Csehingga warna dari HDPE mengalami perubahan. Dalam pembuatannya banyak sekali lelehan yang keluar dari cetakan pada saat proses hotpress berlangsung.

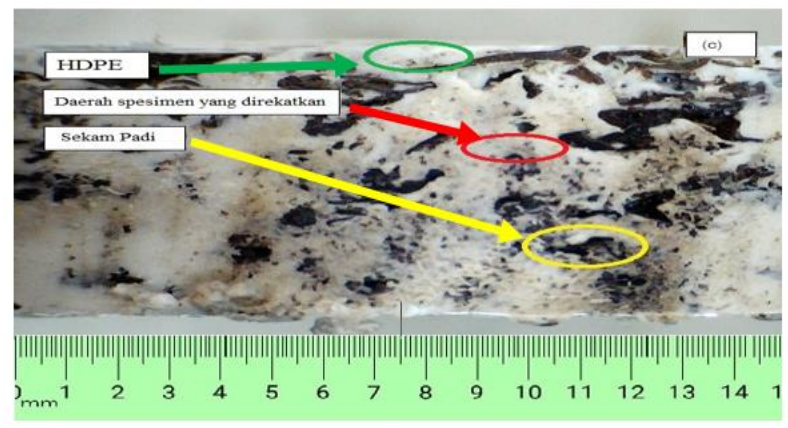

Gambar 9. Foto makro papan komposit proses hopress suhu $200{ }^{\circ} \mathrm{C}$ 
Gambar 11 menunjukan hasil foto makro dengan suhu $220{ }^{\circ}$ Cselama \pm 5 jam pengepresan. Pada pembesaran foto makro terlihat serupa seperti papan komposit dengan pembuatan suhu $200{ }^{\circ} \mathrm{Cdari}$ bentuk dan warna dari sekam-HDPEnya, hanya saja ketebalan dari komposit sekam padi semakin mengalami penyusutan. Secara keseluruhan penyatuan antara sekam-HDPE menutupi dengan baik, namun masih terdapat banyak rongga rongga yang terlihat dikarenakan penyatuan sekam-HDPE kurang menyeluruh. Hal ini juga disebabkan fraksinya, kemudian sifat dari bentuk sekam yang dipanaskan sudah mencapai suhu $200{ }^{\circ} \mathrm{C}$, untuk sifat dari HDPE karena titik lelehnya berkisar $120^{\circ} \mathrm{C}-130$ ${ }^{\circ} \mathrm{C}[13]$ maka jarak suhu sudah jauh pada pembuatan dengan penyetelan mesin hot press di suhu 220 ${ }^{\circ}$ Csehingga warna dari HDPE mengalami perubahan. Dalam pembuatannya terdapat juga lelehan yang keluar dari cetakan pada saat proses hotpress berlangsung.

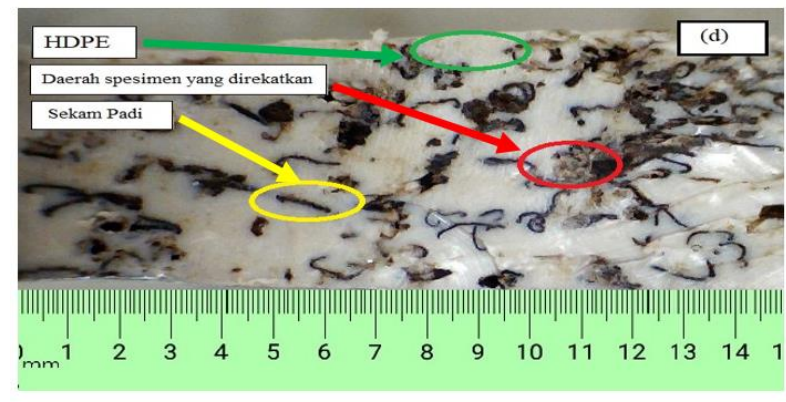

Gambar 10. foto makro papan komposit proses hotpress suhu $220{ }^{\circ} \mathrm{C}$.

Pada Gambar struktur makro 8 sampai dengan Gambar 11, dapat dilihat perbedaan ikatan partikel HDPE terhadap sekam padi. (Gnauck 1991) Partikel HDPE yang dominan akan mampu mengikat komposit secara optimal karena jumlah serat sedikit [14]. Jumlah sekam semakin sedikit menimbulkan potensi menurunnya kekuatan komposit. (Oza 2010) Fenomena tersebut disebabkan semakin sedikit fraksi volume sekam akan meningkatkan rongga atau pori-pori pada komposit. Semakin bertambahnya suhu maka kekuatan komposit semakin menurun [15].

\subsection{Pengujian Tarik}

Dari hasil pengujian tarik membuktikanm bahwa dengan memvariasikan temperatur maka mempengaruhi kekuatan tarik yang di hasilkan [10].

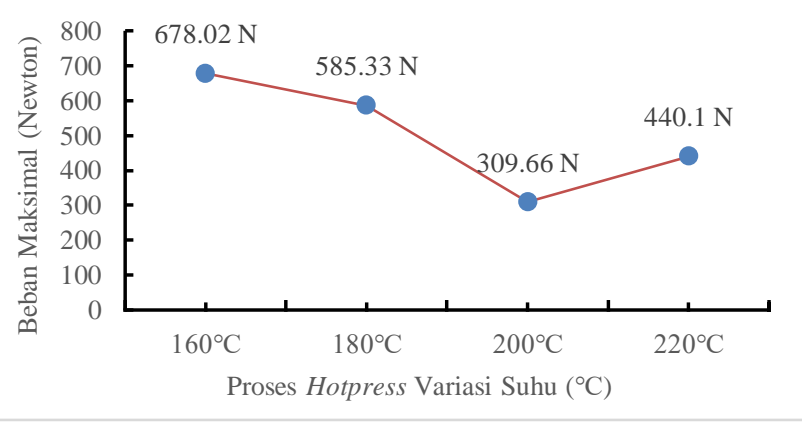

Gambar 11. Grafik hubungan pengaruh antara beban maksimal dengan komposit fraksi $20 \%$ sekam padi: $80 \%$ HDPE proses hotpress variasi suhu $160{ }^{\circ} \mathrm{C}$, $180{ }^{\circ} \mathrm{C}, 200{ }^{\circ} \mathrm{C}, 220{ }^{\circ} \mathrm{C}$.

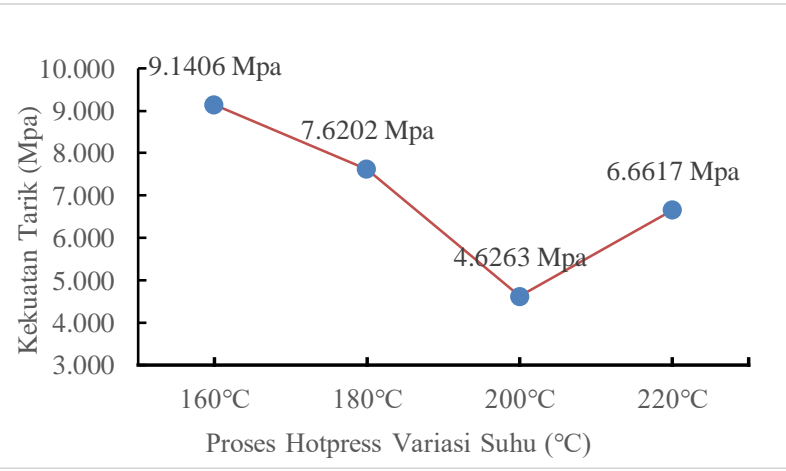

Gambar 12. Grafik hubungan pengaruh antara kekuatan tarik dengan komposit fraksi $20 \%$ sekam padi: $80 \%$ HDPE proses hotpress variasi suhu $160{ }^{\circ} \mathrm{C}, 180{ }^{\circ} \mathrm{C}, 200{ }^{\circ} \mathrm{C}, 220{ }^{\circ} \mathrm{C}$

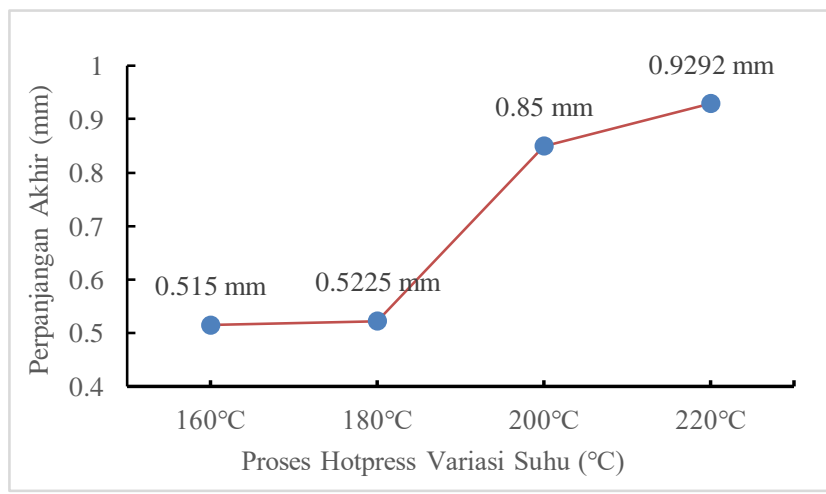

Gambar 13. Grafik hubungan pengaruh antara perpanjangan akhir dengan komposit fraksi $20 \%$ sekam padi: $80 \%$ HDPE proses hotpress variasi suhu $160{ }^{\circ} \mathrm{C}, 180{ }^{\circ} \mathrm{C}, 200{ }^{\circ} \mathrm{C}, 220{ }^{\circ} \mathrm{C}$. 


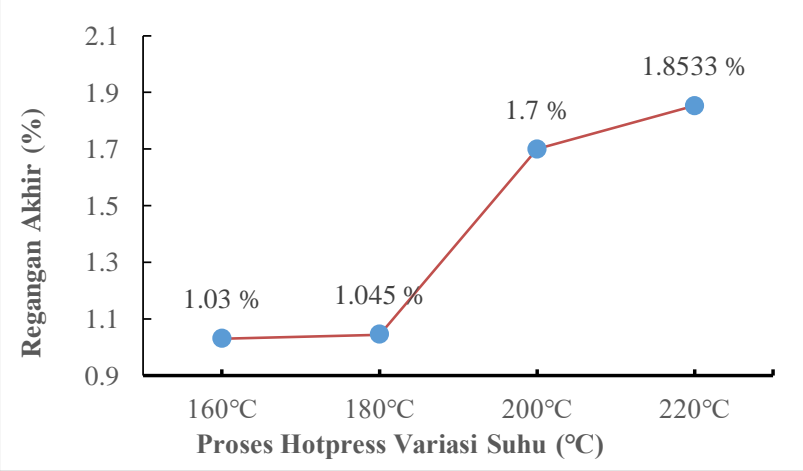

Gambar 14. Grafik hubungan pengaruh antara regangan akhir dengan komposit fraksi $20 \%$ sekam padi: $80 \%$ hdpe proses hotpress variasi suhu $160{ }^{\circ} \mathrm{C}$, $180{ }^{\circ} \mathrm{C}, 200{ }^{\circ} \mathrm{C}, 220{ }^{\circ} \mathrm{C}$

Berdasarkan keterangan grafik yang terlihat pada Gambar 12 - Gambar 15 komposit berpenguat sekam padi matriks HDPE memiliki rata-rata beban maksimal paling besar pada fraksi volume 20\%: 80 $\%$ dengan proses hot press $160{ }^{\circ} \mathrm{Cyaitu}$ sebesar 678.02 N. Kemudian diikuti komposit dengan variasi suhu $180{ }^{\circ} \mathrm{C} ; 220{ }^{\circ} \mathrm{C} ; 200{ }^{\circ} \mathrm{C}$, yang masingmasing sebesar $585.33 \mathrm{~N} ; 440.10 \mathrm{~N} ; 309.66 \mathrm{~N}$. Seperti pada Gambar 12 grafik hubungan pengaruh antara beban maksimal dengan variasi suhu. Komposit berpenguat sekam padi matriks HDPE memiliki rata-rata kekuatan tarik paling besar pada fraksi volume $20 \%: 80 \%$ dengan proses hot press $160{ }^{\circ}$ Cyaitu sebesar 9.1406 MPa. Kemudian diikuti komposit dengan variasi suhu $180{ }^{\circ} \mathrm{C} ; 220{ }^{\circ} \mathrm{C}$; 200 ${ }^{\circ} \mathrm{C}$, yang masing-masing sebesar $7.6202 \mathrm{MPa}$; 6.5517 MPa; 4.6263 MPa. Seperti pada Gambar 13 grafik hubungan pengaruh antara kekuatan maksimal dengan variasi suhu.

Pada Komposit berpenguat sekam padi matriks HDPE memiliki perbedaan yang signifikan yaitu pada rata-rata perpanjangan akhir paling besar fraksi volume $20 \%$ dengan proses hot press adalah suhu $220{ }^{\circ} \mathrm{Cdengan}$ nilai $0.9292 \mathrm{~mm}$. Kemudian diikuti komposit dengan variasi suhu $200{ }^{\circ} \mathrm{C} ; 180{ }^{\circ} \mathrm{C} ; 160$ ${ }^{\circ} \mathrm{C}$, yang masing-masing sebesar $0.8500 \mathrm{~mm}$; 0.5225 $\mathrm{mm} ; 0.5150 \mathrm{~mm}$. Seperti pada Gambar 14 grafik hubungan pengaruh antara perpanjangan akhir dengan variasi suhu. Pada komposit berpenguat sekam padi matriks HDPE memiliki rata-rata regangan akhir paling besar fraksi volume $20 \%$ dengan proses hot press juga bersuhu $220{ }^{\circ} \mathrm{C}$, dengan nilai $1.8533 \%$. Kemudian diikuti komposit dengan variasi suhu $200^{\circ} \mathrm{C}, 180{ }^{\circ} \mathrm{C} ; 160{ }^{\circ} \mathrm{C}$, yang masing- masing sebesar $1.7000 \% ; 1.0450 \% ; 1.0300 \%$. Seperti pada Gambar 125 grafik hubungan pengaruh antara regangan akhir dengan variasi suhu. Keberadaan rongga merupakan tempat konsentrasi tegangan akan menjadi tempat inisiasi/awal retak sehingga komposit yang mengalami tegangan nilai kekuatan tarik menjadi rendah [16]. Bisa disimpulkan juga bahwa pengambilan pemotongan pada bagian papan komposit dapat mempengaruhi hasil kekuatan uji tarik. Kemudian pada penelitian yang dilakukan oleh Setyawan dkk 2012 [17] tentang komposit serat daun nanas memiliki kekuatan tarik maksimal 33,57 MPa dengan fraksi volume $40 \%$ serat $60 \%$ matriks, meningkatnya kekuatan tarik dikarenakan orientasi serat searah dan penambahan komposisi serat.

\section{KESIMPULAN}

Kesimpulan yang didapatkan dari penelitian ini adalah sebagai berikut:

Hasil Pencetakan papan komposit pada suhu 160 ${ }^{\circ} \mathrm{Cdan}$ suhu $180^{\circ} \mathrm{Cterlihat} \mathrm{jelas} \mathrm{HDPE} \mathrm{tidak} \mathrm{melapisi}$ secara menyeluruh terutama pada bagian pinggir cetakan namun pada penyatuan sekam padi-HDPE bagian tengahnya terlihat lebih menyatu dengan optimal. Sedangkan pada suhu $200{ }^{\circ} \mathrm{Cdan} 220$ ${ }^{\circ}$ Cterlihat sangat jelas bahwa HDPE sangat mendominasi cetakan dibandingkan sekam padi, sehingga HDPE melapisi sekam padi dengan optimal untuk ketebalan dari papan komposit menjadi lebih pipih dibandingkan dengan suhu 160 ${ }^{\circ} \mathrm{Cdan}$ suhu $180{ }^{\circ} \mathrm{C}$, hal ini didasari pada karakteristik dari HDPE yang mana titik lelehnya berkisar antara $120{ }^{\circ} \mathrm{C}-135{ }^{\circ} \mathrm{C}$. Hasil foto makro memperlihatkan susunan dari dari papan komposit, bahwa pengaruh variasi suhu dalam metode hotpress menunjukan hasil yang berbeda-beda. Pada proses pembuatan disuhu $160{ }^{\circ}$ Csekam padi terlihat jelas mengisi di bagian tengah spesimen, sekam dan HDPE tidak mengalami perubahan bentuk dan warna. Pada suhu $180{ }^{\circ}$ Csekam padi terlihat juga mengisi dibagian tengah spesimen akan tetapi bentuk dari sekam mulai mengalami penyusutan. Pada suhu $200{ }^{\circ}$ Csekam terlihat sudah banyak mengalami perubahan betuk dan warna, sekam sudah mengalami penyusutan dan tampak hangus sehingga HDPE lebih mendominasi papan komposit. Pada suhu $220{ }^{\circ} \mathrm{Csekam}$ padi 
dan HDPE terlihat mengalami perubahan bentuk dan warna, sekam lebih hangus dan menyusut kemudian HDPE sudah mengalami perubahan warna, sehingga HDPE lebih menddominasi papan komposit. Hasil pengujian mekanik pada uji tarik komposit sekam padi matriks HDPE memiliki beban maksimal dan kekuatan tarik pada pembuatan papan komposit pada suhu 160 yaitu $678,02 \mathrm{~N}$ dan 9,1406 MPa serta memiliki perpanjangan akhir dan regangan akhir yaitu $0,515 \mathrm{~mm}$ dan $1,03 \%$. Sehingga kesimpulannya semakin besar nilai beban maksimal dan kekuatan tarik maka semakin kecil nilai dari perpanjangan dan regangan akhir dari papan komposit sekam padi.

\section{Ucapan Terima Kasih}

Penulis mengucapkan terima kasih kepada Kemenristek DIKTI yang telah mendanai penelitian sehingga penelitian berjalan dengan lancar dan kepada seluruh pihak yang telah memberi dukungan dalam penelitian komposit sekam padi ini. khususnya dosen teknik mesin Univesitas Singaperbangsa Karawang.

\section{DAFTAR PUSTAKA}

[1] Asroni, A., \& Nurkholis, D. (2017). Pengaruh Komposisi Resin Poliester Terhadap Kekerasan Dan Kekuatan Tarik Komposit Papan Partikel Onggok Limbah Singkong. Turbo: Jurnal Program Studi Teknik Mesin, 5(1).

[2] Sarumaha, P. S. B. (2008). Kualitas komposit kayu plastik dari limbah serat buah sawit dan polipropilena daur ulang. Kualitas Komposit Kayu Plastik Dari Limbah Serat Buah Sawit Dan Polipropilena Daur Ulang.

[3] Rita, R., Setyawati, D., \& Usman, F. H. (2015). Sifat Fisik Dan Mekanik Papan Komposit Dari Batang Singkong Dan Limbah Plastik Berdasarkan Pelapisan Dan Komposisi Bahan Baku. Jurnal hutan lestari, 3(2).

[4] Mulana, F., Hisbullah, H., \& Iskandar, I. (2011). Pembuatan papan komposit dari plastik daur ulang dan serbuk kayu serta jerami sebagai filler. Jurnal Rekayasa Kimia \& Lingkungan, 8(1).
[5] Faujiah, Dwiria Wahyuni, dan Boni P. Lapanporo. (2014). Analisis Sifat Fisik Dan Mekanik Papan Partikel Berbahan Dasar Sekam Padi. Positron, IV (2):60-63, 2014.

[6] Sulaiman, S., \& Fauzan, A. (2018). Pengaruh Temperatur Tekan Panas Papan Partikel Berbahan Tandan Kosong Kelapa Sawit Dan Kulit Kayu Pinus Terhadap Sifat Mekanik. Jurnal Momentum, 20(2), 128-132.

[7] Hanifi, Rizal. Marno. Kardiman dan Widianto, Eri., 2019, Rancang Bangun Mesin Hotpress Untuk Pembuatan Papan Komposit Berbasis Limbah Sekam Padi Dan Plasik HDPE. Karawang: Jurusan Teknik Mesin, Fakultas Teknik, Universitas Singaperbangsa Karawang.

[8] Nurhidayat, A. (2013). Pengaruh Fraksi Volume Pada Pembuatan Komposit Hdpe Limbah-Cantuladan Berbagai Jenis Perekat Dalam Pembuatan Laminate (Doctoral dissertation, universitas sebelas maret).

[9] Susilowati, sri endah. Studi Perlakuan Alkali Terhadap Sifat Mekanik Bahan Komposit Berpenguat Sekam Padi. Jurnal Kajian Teknik Mesin, 2017, 2.1: 67-80.

[10] Potluri, R., Paul, K. J., \& Prasanthi, P. (2017). Mechanical properties characterization of okra fiber based green composites \& hybrid laminates. Materials Today: Proceedings, 4(2), 2893-2902

[11] Witono, K., Irawan, Y. S., Soenoko, R., \& Suryanto, H. (2014). Pengaruh perlakuan alkali $(\mathrm{NaOH})$ terhadap morfologi dan kekuatan tarik serat mendong. Rekayasa Mesin, 4(3), 227-234.

[12] Nurhidayat, Achmad., 2014, Pengaruh Fraksi Volume Pada Pembuatan Komposit HDPE Limbah Cantula dan Berbagai Jenis Perekat Dalam Pembuatan Laminate. Surakarta: Program Studi Magister Teknik Mesin, Fakultas Teknik, Universitas Sebelas Maret Surakarta.

[13] Slamet, S. (2013). Karakterisasi Komposit Dari Serbuk Gergaji Kayu (Sawdust) Dengan Proses Hotpress Sebagai Bahan Baku Papan Partikel. Prosiding SNST Fakultas Teknik,

[14] Gnauck, A. H., Korotky, S. K., Veselka, J. J., Nagel, J., Kemmerer, C. T., Minford, W. J., \& Moser, D. T. (1991). Dispersion penalty reduction using an optical modulator with 
adjustable chirp. IEEE Photonics Technology Letters, 3(10), 916-918.

[15] Oza, V. P., Parmar, P. P., Kumar, S., \& Subramanian, R. B. (2010). Anticancer properties of highly purified L-asparaginase from Withania somnifera L. against acute lymphoblastic leukemia. Applied biochemistry and biotechnology, 160(6), 1833-1840.

[16] Setyawan, P. D., Sari, N. H., \& Putra, D. G. P. (2012). Pengaruhorientasi dan fraksi volume serat daun nanas (ananas comosus) terhadap kekuatan tarik komposit polyestertak jenuh (up). Dinamika teknik mesin: jurnal keilmuan dan terapan teknik mesin, 2(1). 